\title{
THE EFFECT OF N-STEAROYLETHANOLAMINE ON ADIPOCYTES FREE CHOLESTEROL CONTENT AND PHOSPHOLIPID COMPOSITION IN RATS WITH OBESITY-INDUCED INSULIN RESISTANCE
}

\author{
O. S. DZIUBA, Ie. A. HUDZ, H. V. KOSIAKOVA, T. M. HORID'KO, \\ V. M. KLIMASHEVSKY, N. M. HULA
}

\begin{abstract}
Palladin Institute of Biochemistry, National Academy of Sciences of Ukraine, Kyiv; e-mail: oksana.dziuba86@gmail.com
\end{abstract}

\begin{abstract}
Obesity induces molecular changes that promote associated disorders, such as insulin resistance (IR) and type 2 diabetes. Low insulin sensitivity occurs primarily due to defects in the pathway of insulin action in target tissues, and there is a hypothesis that IR may originate in adipose tissue and is followed by dyslipidemia. In this study using methods of thin-layer and gas-liquid chromatography we investigated free cholesterol content and phospholipid composition of adipocytes of obesity-induced IR rats and its changes induced by the N-stearoylethanolamine (NSE) administration. The results we obtained demonstrated that free cholesterol content significantly increased in adipocytes of IR rats compared to control. The analysis of phospholipid composition indicated a reduction of phosphatidylcholine and the total content of phosphatidylinositol with phosphatidylserine, whereas the content of lysophosphatidylcholine, sphingomyelin and phosphatidylethanolamine increased in IR group compared to control. As far as NSE administration caused a statistically significant decrease in free cholesterol level and had a considerable effect on normalization of individual phospholipids content of adipocytes, we can consider NSE as a prospective compound worthy more complex investigation of its action under the pathological conditions.
\end{abstract}

Keywords: N-stearoylethanolamine, cholesterol content, phospholipids, adipose tissue, obesity, experimental insulin resistance.

I $\mathrm{t}$ is known that obesity is a complex metabolic disorder often associated with insulin resistance (IR) as well as type 2 diabetes [1]. Chronic hypernutrition and high fat diet rich in saturated fatty acids leads to molecular changes in insulin sensitive tissues (liver, muscle and adipose tissue) and impairment in insulin signaling [2].

Low insulin sensitivity occurs primarily due to defects in the pathway of insulin action in target tissues, and there is a hypothesis that IR may originate in adipose tissue and may be followed by dyslipidemia [3, 4]. Cholesterol is known as the main modulator of phospholipids content in cell membranes $[5,6]$.

Recent studies indicate that $\mathrm{N}$-acylethanolamines (NAEs) regulate energy homeostasis by interacting with the nuclear and orphan receptors.

It was previously shown that saturated NAE $\mathrm{N}$-stearoylethanolamine (NSE) is able to regulate the lipid content of biological membranes under the different pathological conditions [7]. The membranestabilizing and anti-inflammatory action of NSE was shown on different tissues (the liver, pancreas, heart, skin, testes) in a wide range of pathological conditions in animal models [8-10]. The main effect of NSE has been suggested to be the improvement of lipid imbalance, and the results of previous studies demonstrated that NSE influences positively the lipid composition of such insulin sensitive tissues as the liver and pancreas and this effect is also associated with the improvement of insulin sensitivity in rats with obesity-induced IR [11, 12].

That is why the aim of our study was to investigate the free cholesterol content and phospholipid

(c) 2018 Dziuba O. S. et al. This is an open-access article distributed under the terms of the Creative Commons Attribution License, which permits unrestricted use, distribution, and reproduction in any medium, provided the original author and source are credited. 
composition of adipocytes of obesity-induced insulin resistant rats and these changes induced by the $\mathrm{N}$-stearoylethanolamine administration.

\section{Materials and Methods}

Animal model. The study was carried out on male outbred rats with average weight $170 \pm 4$ g. All experiments involving animals were carried out with an approval of the Animal Care and Use Committee of the Palladin Institute of Biochemistry of the NAS of Ukraine and in accordance with the General Ethical Principles on Experiments with Animals of the first National Congress on Bioethics (Kyiv, 2001).

Rats were housed in standard cages with free access to food and water. Obesity-induced IR was obtained by feeding a prolonged high-fat diet (HFD) during 6 month [13]. The diet included pellets with addition of visceral lard. Component analysis of HFD [14] demonstrated that total content of fat, proteins and carbohydrates was 58, 23 and $10 \%$, respectively. The fatty acids composition of HFD was at a ratio of 55\% saturated (SFA) and 45\% unsaturated (USFA) fatty acids. The animals from control group received standard pellet diet containing $4 \%$ of fat, $23 \%$ of proteins and $65 \%$ of carbohydrates with the percentage of SFA and USFA 38 and 62\%, respectively.

On the $24^{\text {th }}$ week, the average weight of HFD rats was $383 \pm 12 \mathrm{~g}$ compared to control rats of $279 \pm 7 \mathrm{~g}$. The dynamic of rats' body weight and glucose level in blood are presented in Fig. 1 and Fig. 2.

Six months after HFD period, we conducted the oral glucose tolerance test [15]. After 12-hour fasting period and measurement of the blood glucose level, rats received water solution of glucose at a dosage of $1 \mathrm{~g}$ per $1 \mathrm{~kg}$ body weight. This animal model of obesity-induced IR was thoroughly investigated in earlier studies and it was confirmed by the homeostatic model assessment (HOMA) that IR strongly correlated with impairment of glucose tolerance [11]. In our study the rats with impaired glucose tolerance (the level of blood glucose within $150 \mathrm{~min}$ after the oral glucose administration was higher than $5 \mathrm{mmol} / \mathrm{l}$ ) were selected and divided randomly into two groups: IR $(n=12)$ and IR+NSE $(n=15)$. Control rats were divided into Control $(n=9)$ and Control+NSE $(n=11)$ groups. The results of the oral glucose tolerance test for control and IR animals are presented in the Fig. 3.

Animals in Control+NSE and IR+NSE groups received orally via intragastric probe the water sus-

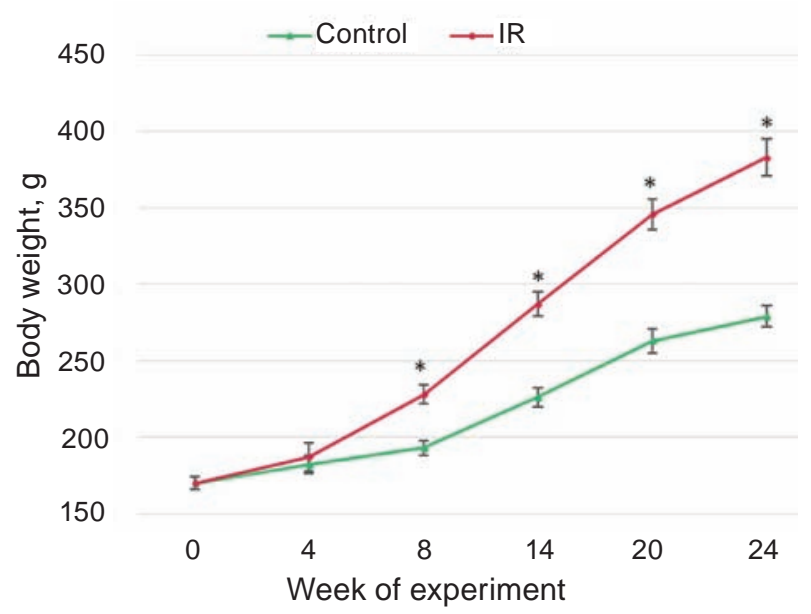

Fig. 1. Body weight of rats. Values represented mean \pm SEM. Values in control $(n=20)$ and $I R$ ( $n=27)$ groups were compared. ${ }^{*} P<0.05$ compared to the control group

pension of NSE for 14 days at a dosage of $50 \mathrm{mg}$ per $1 \mathrm{~kg}$ body weight. At the end of the experiment, the rats were decapitated under Nembutal anesthesia (50 mg/kg body weight) [16].

The abdominal fat was immediately removed for further adipocytes isolation.

Adipocytes isolation. One gram of abdominal fat pad isolated from rats was digested by Type 1 Collagenase solution in HEPES buffer ( $\mathrm{pH} 7.4)$ according to the modified Rodbell procedure [17, 18]; $2 \mathrm{ml}$ of Krebs-Ringer HEPES Buffer ( $\mathrm{pH}$ 7.4) was added to $1 \mathrm{~g}$ of rat abdominal adipose tissue. Krebs-

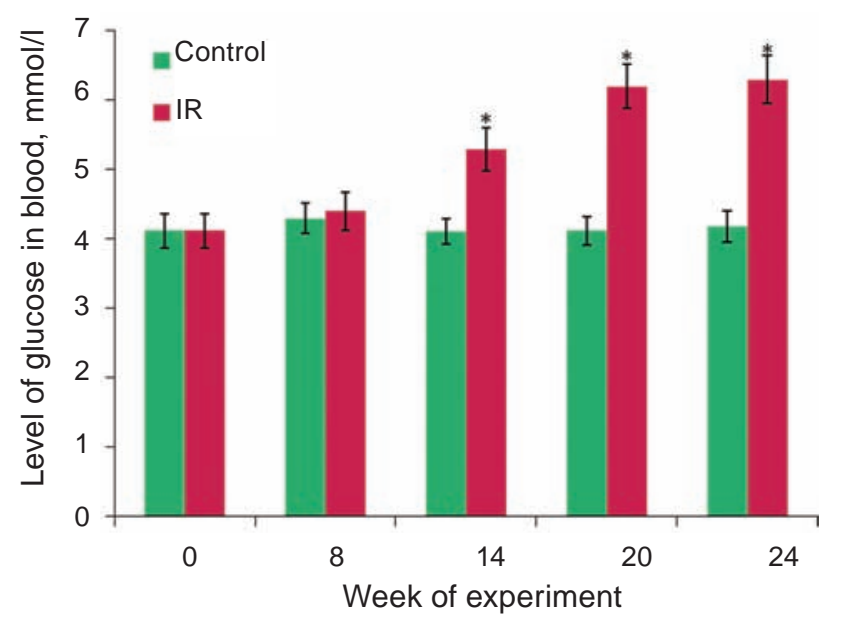

Fig. 2. The level of glucose in blood. Values represented mean \pm SEM. Values in control $(n=20)$ and IR $(n=27)$ groups were compared. ${ }^{*} P<0.05 \mathrm{com}-$ pared to the control group 


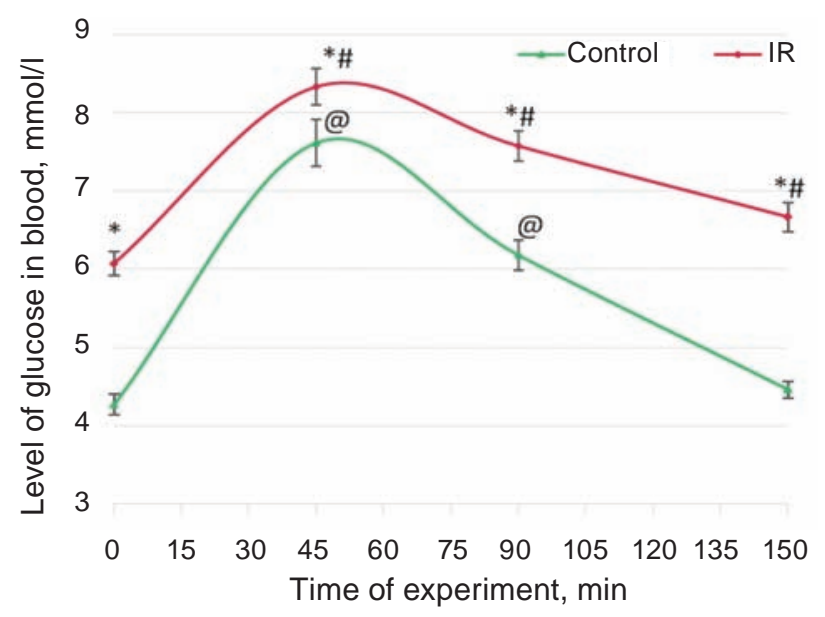

Fig. 3. Changes of glucose level in rats' blood during glucose tolerance test. Values represented mean \pm SEM. Values in control $(n=20)$ and $I R$ $(n=27)$ groups were compared. ${ }^{*} P<0.05$ compared to the control group at the same time of experiment; ${ }^{\#} P<0.05$ compared to the IR group at the 0 min of experiment; ${ }^{\circledR} P<0.05$ compared to the control group at the 0 min of experiment

Ringer HEPES Buffer contains $5 \mathrm{mM}$ D-Glucose, 2\% BSA, $135 \mathrm{mM} \mathrm{NaCl}, 2.2 \mathrm{mM} \mathrm{CaCl}{ }_{2} \times 2 \mathrm{H}_{2} \mathrm{O}$, $1.25 \mathrm{mM} \mathrm{MgSO}_{4} \times 7 \mathrm{H}_{2} \mathrm{O}, 0.45 \mathrm{mM} \mathrm{KH}_{2} \mathrm{PO}_{4}, 2.17 \mathrm{mM}$ $\mathrm{Na}_{2} \mathrm{HPO}_{4}, 10 \mathrm{mM}$ HEPES.

Adipose tissue in buffer was thoroughly minced by scissors (1-2 $\mathrm{mm}$ pieces). Buffered tissue fragments were digested with Type 1 Collagenase solution in the same buffer $(1.25 \mathrm{mg} / \mathrm{ml})$ at $37{ }^{\circ} \mathrm{C}$ with periodical gentle shaking for $1 \mathrm{~h}$. After incubation the tissue suspension was diluted in $1 \mathrm{ml}$ of cold buffer and isolated adipocytes were separated from undigested tissue by the filtration through the $400 \mu \mathrm{m}$ nylon mesh and washed by $1 \mathrm{ml}$ of buffer three times. The resulting cell suspension was centrifuged at $1000 \mathrm{rpm}$ for $10 \mathrm{~min}$ and floating adipocytes were separated from the stromal vascular fraction.

Lipids extraction from adipocytes. Total lipids from the adipocytes were extracted and purified according to the Blight and Dyer methods [19] with minor modifications. Three milliliters of solvent system of chloroform/methanol (2:1, v/v) were added to $1 \mathrm{ml}$ of adipocyte suspension, and after 30 seconds vortexing the mixture was centrifuged during $15 \mathrm{~min}$ at $250 \mathrm{~g}$. The lower chloroform layer was transferred to a flask. After that $2 \mathrm{ml}$ of chloroform were added to residuary methanol fraction, vortexed during $30 \mathrm{sec}$ and centrifuged again in the same conditions for total extraction of lipids. The removed chloroform layers after extraction and re-extraction were integrated for further aspiration. After measuring the weight of dry lipid extracts, $500 \mu \mathrm{l}$ of benzene were added to each sample.

Separation of lipid fractions. Lipid fractions separation was carried by thin-layer chromatography on a silica-gel-coated plates with $110 \mu \mathrm{m}$ layer thickness using a solvent system of hexane: diethyl ether: acetic acid with component ratio by volume 85:15:1.

Cholesterol content determination. After separation of lipid extract by thin-layer chromatography, the cholesterol fraction was eluted by $3 \mathrm{ml}$ of diethyl ether. Following evaporation of the solvent, the dry residue was assayed by gas-liquid chromatography on a glass column $(0.5 \mathrm{~m})$ packed with $1.5 \% \mathrm{OV}-1$ on 80-100 mesh Chimalite at $250{ }^{\circ} \mathrm{C}$. The concentration of cholesterol was calculated by the difference between peak areas of the samples and the peak of the purified cholesterol standard.

Phospholipid composition determination. After separation of lipid extract by thin-layer chromatography, the phospholipid fraction was transferred into solvent mixture containing $2 \mathrm{ml}$ of chloroform, $1 \mathrm{ml}$ of methanol and $0.8 \mathrm{ml}$ of distilled water. After vortexing during $1 \mathrm{~min}$ and centrifugation during 2-3 min at $1000 \mathrm{~g}$, the lower chloroform layer was transferred to a flask, evaporated and solved in $0.15 \mathrm{ml}$ of benzene. Such a refined lipid extract was used for the analysis of individual phospholipids (PL) content.

The individual PL content was determined by refined lipid extract separation with 2D thin-layer chromatography on a silica-gel-coated plates with $110 \mu \mathrm{m}$ thick layer.

Solvent system for the first dimension was chloroform (65): methanol (30): ammonia (6): benzene $(10)(v / v)$, and the second dimension was with chloroform (5): methanol (1): acetic acid (1): water $(0.5)$ : acetone $(2)(\mathrm{v} / \mathrm{v})[20,21]$. The amount of individual PL was estimated by colorimetric measurement of inorganic phosphate [P(i)] in each separated PL spot using the Vaskovskiy and Kostetskiy method [22] and determined spectrophotometrically as their phosphomolybdenum blue complex in the $815 \mathrm{~nm}$ wavelength region.

Statistical analysis. The data, presented as mean values \pm standard errors of the means (SEM) from different studied groups were compared by the Student's unpaired $t$-test for samples with normal distribution using software MS Office Excel. The statistics of significance was determined at $P<0.05$. 


\section{Results and Discussion}

Adipocyte free cholesterol content. Free cholesterol content of rat adipocytes is presented on Fig. 4. The determination of the free cholesterol content in rat adipocytes showed a considerable increase in IR group, which was significantly higher than those of controls (Fig. 4). The administration of NSE did not caused any significant changes in adipocytes free cholesterol content of rats from the group Control+NSE. However, NSE caused a statistically significant decrease in free cholesterol content of white adipose tissue cells in a group of obesityinduced IR rats (Fig. 4).

Cholesterol is recognized as the main modulator of cell membranes phospholipid composition. It is also well known that the content of cholesterol may vary under different pathological conditions [23-25].

It is evident from the chart (Fig. 4) that the prolonged fat overload leads to a significant increase of free cholesterol level in rat adipocytes. It is known that all cholesterol present in the organism arises from two different sources: it can be either synthesized de novo or obtained through food ingestion [26]. It is important to notice that the quantity of cholesterol produced by the organism itself is enough for body requirements and only small part of total cholesterol comes from ingested food [27]. The cholesterol level is maintained through regulation of the synthesis and absorption [28]. Dietary intake of large amount of saturated fat in the form of saturated fatty acids leads to the increase of cholesterol

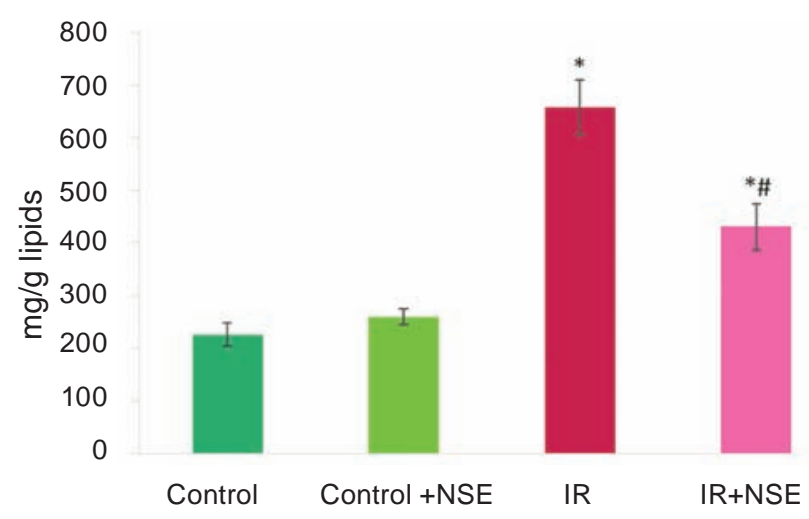

Fig. 4. Free cholesterol content in adipocytes. Values represented mean \pm SEM. Values in Control $(n=9)$, Control+NSE ( $n=11), I R(n=12)$, and IR+NSE group $(n=15)$ were compared. $* P<0.05$ compared to the "Control" group; ${ }^{\#}<0.05$ compared to the "IR" group synthesis and reduction of its removal from the cell membranes. Dietary surplus of saturated fatty acids breakdowns through $\beta$-oxidation to acetyl-CoA, which is involved in the cascade of cholesterol synthesis [26, 28].

Taking into account that experimental animals were not overloaded with dietary cholesterol but fed with diet rich in saturated (palmitic and stearic) fatty acids, the high level of adipocytes free cholesterol may be associated with its hyperproduction from fatty acids as well as impaired mechanisms of its turnover through esterification.

According to the results of dietary components analysis [14], standard pellets are rich in unsaturated fatty acids (oleic, linoleic, linolenic, eicosatrienoic) whereas visceral lard as a main component of HFD contains a majority of saturated (palmitic, stearic) and monounsaturated (oleic) fatty acids. However, the cholesterol content of visceral lard was not high (0.57 mg/g) [14]. Thus, we can assume that the increase of free cholesterol content of HFD-rat adipocytes was caused by the consumption of food rich in saturated fatty acids but not in cholesterol itself.

The data obtained showed that NSE administration contributed significantly to the decrease in free cholesterol content of adipocytes of rats with obesity-induced IR. It is known that acylation is the main mechanism of cholesterol removing from the cell membranes and lecithin-cholesterol acyltransferase (LCAT) with acyl-CoA: cholesterol acyltransferase (ACAT) are the key enzymes catalyzed in this metabolic pathway.

The LCAT bonded to a lipoprotein cleaves the fatty acid from phosphatidylcholine in sn-2 position and transfers it onto the A-ring of cholesterol with further transesterification to the 3- $\beta$-hydroxyl group for cholesterol ester formation. Lysophosphatidylcholine is also formed as a by-product of the reaction [29, 30]. In turn, ACAT uses free fatty acids pool for cholesterol esterification. However, LCAT is considered to have the main transport function.

Probably the effect of NSE is to intensify the cholesterol withdrawal from the adipocyte membrane. It was shown in previous studies, using the same animal model, that NSE administration caused the reduction of free cholesterol content and increase of its esterified form in the liver [26]. There are also the results of in vitro studies that saturated NAEs modulate LCAT activity [31].

Adipocyte phospholipid composition. The analysis of phospholipid composition of adipocytes indicated a reduction of phosphatidylcholine (PC) 
and the total content of phosphatidylinositol with phosphatidylserine (PI+PS), whereas the content of lysophosphatidylcholine (LPC), sphingomyelin (SM) and phosphatidylethanolamine (PE) was increased in IR group compared to Control group (Fig. 5).

It is widely known that phospholipids and cholesterol play an essential role in plasma cell membranes functioning. These components provide fluidity, viscosity and elastic stiffness as well as regulate the membrane-bound enzymes activity and receptor functions, in particular, the transfer of insulin signals in insulin-sensitive tissues [23, 24].

Recent studies indicated the correlation between cell membrane PL composition and markers of insulin resistance of insulin sensitive tissues [32]. In particular, it has been shown that the growth of SM content in membranes of insulin-sensitive cells inhibits a tyrosine kinase, which leads to insulin signaling impairment and contributes to insulin resistance development [33]. There are also studies demonstrating that the content of SM in cell membrane correlates directly with its stiffness and there are the data which suggest that SM could also be a contributor to the dysregulation of genes in obesity [34].

Interestingly, there was a significant increase in the SM level of IR obese rats' adipocytes com- pared to control. Although the increase in SM level in Control+NSE group was also observed, these changes were not significant. The statistically significant reduction of SM content in adipocytes was also observed under NSE treatment.

The results of our experiment demonstrated a decrease of PC content of adipocytes received from obese animals. The data obtained were pretty unexpected because PC is one of the main membrane components and it is known that normally the level of this phospholipid should increase as a response to growth of the content of cell membrane cholesterol. The review of current research works in the field of lipidology showed that there is a correlation between membranes phospholipid composition of insulin-sensitive tissues and obesity-induced insulin resistance [32].

The explanation of PC decrease in obese IR rat adipocytes could also lay in regulation of activity of specific enzymes - phospholipases C and D. According to different authors [35-37], insulin stimulates the degradation of PC in cells from insulinsensitive tissues through the activation of phospholipase $C$ and phospholipase D. Due to the fact that in the condition of insulin resistance the amount of insulin synthesized by the pancreas compensatory increased, the activity of phospholipases $\mathrm{C}$ and $\mathrm{D}$ in

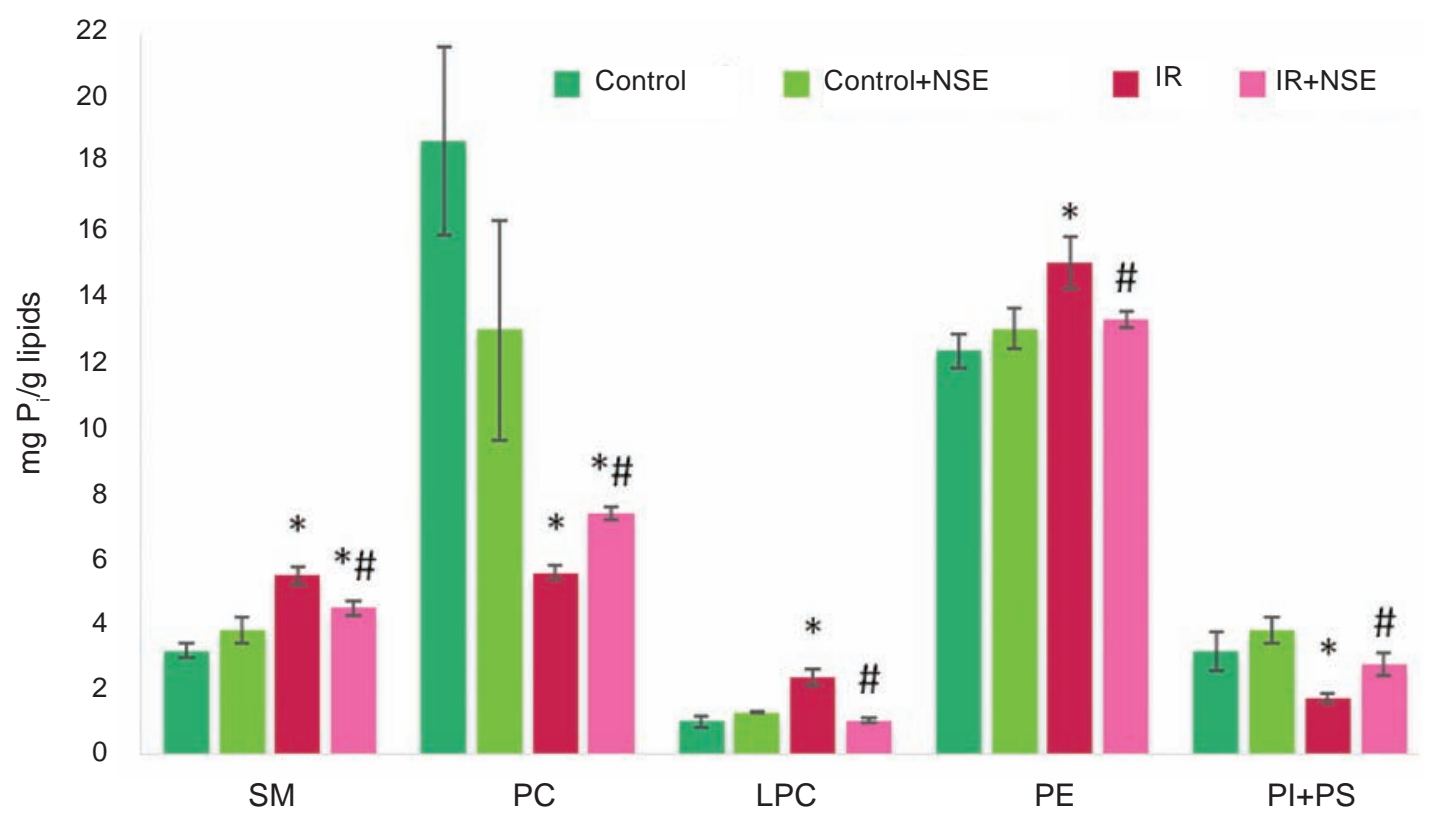

Fig. 5. Phospholipid composition of adipocytes: SM - Sphingomyelin, PC - Phosphatidylcholine, LPC Lysophosphatidylcholine, PE - Phosphatidylethanolamine, PI+PS - Phosphatidylinositol with Phosphatidylserine. Values represented mean \pm SEM. Values in Control $(n=9)$, Control $+N S E(n=11), I R(n=12)$, and $I R+N S E$ group $(n=15)$ were compared. ${ }^{*} P<0.05$ compared to the Control group; ${ }^{*} P<0.05$, compared to the IR group 
experimental animals probably also increased, which could lead to the intensification of PC transformation in adipocytes. It is also obviously, such a decrease of PC is due to the fact that PC is a substrate for the synthesis of lyso-form of PC (LPC). The administration of NSE contributed to the normalization of the LPC content and significant growth of the PC content. It is known that phospholipid lyso-form synthesis in cell membranes occurs mostly with phospholipase A2 participation. There are also publications which described saturated NAEs as regulators of phospholipase A2 activity [38].

Consequently, the results obtained may be the evidence of NSE inhibition action on phospholipase A2 as well as phospholipase $\mathrm{C}$ and phospholipase D. On the other hand, it is known that in mammalian cells CDP-choline, which is a precursor of PC, is synthesized under the action of CTP:phosphocholine cytidylyltransferase. NSE administration could lead to activation of the enzyme which had affinity for membranes depleted of PC and it is the possible mechanism of PC synthesis stimulation [39].

Despite the fact that PE is a major lipid component of membranes, its growth causes significant changes in the physical and chemical properties of the membrane and, as a result, reflected in the membrane-bound enzymes activity. In particular, it has been described that an increase in PE content caused a decrease in the activity of protein kinase $\mathrm{C}$ (PKC) which is a key enzyme of the insulin signaling cascade [40].

Therefore, the PE content in membranes of the insulin-dependent tissues correlates directly with insulin resistance. In addition, some studies have shown that PE may affect the activity of hormonesensitive lipase of adipose tissue, in particular, the growth of PE content can give rise to the enzyme activity [41]. Normalization of PE content in adipocytes of obese rats under the NSE treatment may affect the enzyme activity and thus contribute to a decrease in IR development. Taking into account the results of recent studies, that indicated the ability of NAEs to regulate lipid metabolism via interaction with the nuclear receptors PPAR [42-44], we suggest that NSE takes influence on PPAR which as the transcription factors regulate the expression of synthesis of key enzymes of lipid de novo synthesis.

It is also well known that anionic phospholipids, which include PI and PS, play a specific role in determining the topology of membrane-bound pro- teins. Thus, PKC is one of the most studied transmembrane enzymes, which interacts stoichiometrically with PS in the C2 domain. The results of in vitro studies [45] demonstrated the dependence of PKC atypical forms activation on the PS content.

There is evidence that atypical PKC forms $(\zeta$ and $\mathrm{r} / \lambda$ ) involved in the activation of the glucose- 4 transporter translocation, in contrast to other isoforms of its enzyme, are regulated by PS content only [46]. It is well known that PI is a substrate in the formation of phosphoinositides, which are modulators of the activity of tyrosine-dependent protein kinases [47].

Therefore, the significant probable decrease in PI and PS content in adipocytes of IR rats may indicate the insulin signaling disorders. It is important to notice that similar changes in anionic phospholipids were detected in the liver of obesityinduced IR rats [11]. At the same time, a normalization of PI and PS content of adipocytes was observed after two-week administration of NSE. In previous studies it was demonstrated that NSE take a positive influence on blood glucose level, insulin level as well as results of oral glucose tolerance test [48].

Consequently, administration of NSE significantly reduced the disorders in adipocyte individual phospholipid composition of rats with obesityinduced IR. Such effects of NSE may be due to the modulatory effects on cholesterol level in membranes as well as the direct membranotropic action of the compound, which is associated with the stabilization of the lamellar phase in the locus it is embedded [49].

The results obtained show that prolonged HFD caused not only the increase of body weight but also led to impairment of glucose utilization mechanisms which is likely to develop as a result of lipid imbalance of insulin sensitive tissues. Such consequences were proved in our study dedicated to the investigation of changes in lipid composition of adipose tissue, particularly in content of free cholesterol and phospholipids which are mainly contained in adipocyte membranes.

Such factors as the diet must be taken into account when insulin resistance and type 2 diabetes as well as other obesity-induced complications are considered. It is clear from our observation that hypernutrition and diet rich in saturated fatty acids cause lipid imbalance characterized by structural changes in adipocyte membranes. Thus, the growth of free cholesterol content seems to confirm this idea. On the other hand, changes in phospholipid 
composition may be induced as a compensatory mechanism in response to the increase of cholesterol synthesis.

In conclusion, as far as NSE administration caused a statistically significant decrease in free cholesterol level and had a considerable effect on normalization of individual phospholipids content of adipocytes, we can consider NSE as a prospective compound worth more complex investigation of its action mechanisms in pathological condition.

\section{ВПЛИВ \\ N-СТЕАРОЇЛЕТАНОЛАМІНУ \\ НА ВМІСТ ВІЛЬНОГО \\ ХОЛЕСТЕРОЛУ ТА \\ ІНДИВІДУАЛЬНИХ ФОСФОЛІПІДІВ \\ В АДИПОЦИТАХ ЩУРІВ 3 \\ ІНДУКОВАНОЮ ОЖИРІННЯМ ІНСУЛІНОРЕЗИСТЕНТНІСТЮ}

\section{О. С. Дзюба, С. А. Гудзь, Г. В. Косякова, \\ T. М. Горідько, В. М. Клімашевський, Н. М. Гула}

\author{
Інститут біохімії ім. О. В. Палладіна \\ НАН України, Київ; \\ e-mail: oksana.dziuba86@gmail.com
}

Ожиріння часто призводить до інсулінорезистентності (IP) та розвитку цукрового діабету 2-го типу. Зниження чутливості до інсуліну розвивається внаслідок порушень в шляхах сигналювання інсуліну, й доведено, що інсулінорезистентність виникає і в жировій тканині, супроводжуючись дисліпідемією. В цій роботі методами тонкошарової та газорідинної хроматографії ми дослідили вплив N-стеароїлетаноламіну на вміст вільного холестеролу та індивідуальних фосфоліпідів в адипоцитах щурів 3 індукованою ожирінням інсулінорезистентністю. Одержані результати показали, що рівень вільного холестеролу значно підвищувався в адипоцитах IP-щурів порівняно 3 контрольними. Аналіз фосфоліпідного складу засвідчив зменшення вмісту фосфатидилхоліну та сумарної кількості фосфатидилінозитолу й фосфатидилсерину в адипоцитах IP-тварин, в той час як кількість лізофосфатидилхоліну, сфінгомієліну та фосфатидилетаноламіну збільшувалася в групі IР-щурів порівняно з контрольною. Застосування N-стеароїлетаноламіну спричинювало вірогідне зниження вільного холестеролу та мало позитивний ефект на нормалізацію фосфоліпідної композиції адипоцитів. Одержані дані є підставою розглядати N-стеароїлетаноламін як сполуку, перспективну для подальшого дослідження її дії за різних патологічних станів.

К л ю ч о в і с л о в а: N-стеароїлетаноламін, холестерол, фосфоліпіди, жирова тканина, ожиріння, інсулінорезистентність.

\section{ВЛИЯНИЕ N-СТЕАРОИЛЭТАНОЛАМИНА НА СОДЕРЖАНИЕ СВОБОДНОГО ХОЛЕСТЕРОЛА И ИНДИВИДУАЛЬНЫХ ФОСФОЛИПИДОВ В АДИПОЦИТАХ КРЫС С ИНДУЦИРОВАННОЙ ОЖИРЕНИЕМ ИНСУЛИНОРЕЗИСТЕНТНОСТЬЮ}

\author{
О. С. Дзюба, Е. А. Гудзь, Г. В. Косякова, \\ Т. Н. Горидько, В. М. Климашевский, \\ Н. М. Гулая
}
Інститут биохимии им. А. В. Палладина НАН Украины, Киев; e-mail: oksana.dziuba86@gmail.com

Ожирение часто приводит к инсулинорезистентности (ИР) и развитию сахарного диабета 2-го типа. Снижение чувствительности к инсулину развивается в результате нарушений в путях сигналинга инсулина, и установлено, что инсулинорезистентность возникает и в жировой ткани, сопровождаясь дислипидемией. В этой работе методами тонкослойной и газожидкостной хроматографии мы изучили влияние N-стеароилэтаноламина на содержание свободного холестерола и индивидуальных фосфолипидов в адипоцитах крыс с индуцированной ожирением инсулинорезистентностью. Полученные результаты показали, что уровень свободного холестерола значительно повышался в адипоцитах ИР-крыс по сравнению с контрольными. Фосфолипидный анализ продемонстрировал снижение содержания фосфатидилхолина и суммарного количества фосфатидилинозитола и фосфатидилсерина в адипоцитах ИР-животных, в то время как количество лизофосфатидилхолина, сфингомиелина и фосфатидилэтаноламина возростало в группе ИР-крыс по сравнению с контрольной. Приме- 
нение N-стеароилэтаноламина вызывало достоверное снижение свободного холестерола и оказывало позитивный эффект на нормализацию фосфолипидной композиции адипоцитов. Полученные данные являются основаним для рассмотрения N-стеароилэтаноламина как соединения, перспективного для дальнейших исследований его действия при различных патологиях.

К л юч е в ы е с лов а: $\mathrm{N}$-стеароилэтаноламин, холестерол, фосфолипиды, жировая ткань, ожирение, инсулинорезистентность.

\section{References}

1. Eckel RH, Kahn SE, Ferrannini E, Goldfine AB, Nathan DM, Schwartz MW, Smith RJ, Smith SR. Obesity and type 2 diabetes: what can be unified and what needs to be individualized? J Clin Endocrinol Metab. 2011; 96(6): 1654-1663.

2. Sears B, Perry M. The role of fatty acids in insulin resistance. Lipids Health Dis. 2015; 14: 121.

3. Jung UJ, Choi MS. Obesity and its metabolic complications: the role of adipokines and the relationship between obesity, inflammation, insulin resistance, dyslipidemia and nonalcoholic fatty liver disease. Int J Mol Sci. 2014; 15(4): 6184-6223.

4. Mittendorfer B. Origins of metabolic complications in obesity: adipose tissue and free fatty acid trafficking. Curr Opin Clin Nutr Metab Care. 2011; 14(6): 535-541.

5. Dawaliby R, Trubbia C, Delporte C, Noyon C, Ruysschaert JM, Van Antwerpen P, Govaerts C. Phosphatidylethanolamine Is a Key Regulator of Membrane Fluidity in Eukaryotic Cells. J Biol Chem. 2016; 291(7): 3658-3667.

6. Ohvo-Rekilä H, Ramstedt B, Leppimäki P, Slotte JP. Cholesterol interactions with phospholipids in membranes. Prog Lipid Res. 2002; 41(1): 66-97.

7. Kosiakova GV, Gula NM. The N-stearoylethanolamine effect on the NO-synthase way of nitrogen oxide formation and phospholipid composition of erythrocyte membranes in rats with streptozotocine diabetes. Ukr Biokhim Zhurn. 2007; 79(6): 53-59. (In Ukrainian).

8. Goridko TM, Gula NM, Stogniy NA, Meged OF, Klimashevsky VM, Shovkun SA, Kindruk NL, Berdyshev AG. Influence of $\mathrm{N}$-stearoylethanolamine on the lipid peroxidation process and lipid composition of the rat liver under acute morphine intoxication. Ukr Biokhim Zhurn. 2007; 79(5): 175-185. (In Ukrainian).

9. Gula NM, Chumak AA, Berdyshev AG, Meged EF, Goridko TM, Kindruk NL, Kosyakova GV, Zhukov OD. Anti-inflammatory effect of N-stearoylethanolamine on experimental burn wound in rats. Ukr Biokhim Zhurn. 2009; 81(2): 107-116. (In Ukrainian).

10. Goridko TM, Kosiakova GV, Berdyschev AG, Bazylyanska VR, Margitich VM, Gula NM. The influence of $\mathrm{N}$-stearoylethanolamine on the activity of antioxidant enzymes and on the level of stable NO metabolites in the rat testes and blood plasma at the early stages of streptozotocine-induced diabetes. Ukr Biokhim Zhurn. 2012; 84(3): 37-43. (In Ukrainian).

11. Onopchenko OV, Kosiakova GV, Goridko TM, Klimashevsky VM, Hula NM. The effect of $\mathrm{N}$-stearoylethanolamine on liver phospholipid composition of rats with insulin resistance caused by alimentary obesity. Ukr Biochem $\mathrm{J}$. 2014; 86(1): 101-110. (In Ukrainian).

12. Onopchenko OV, Kosiakova GV, Oz M, Klimashevsky VM, Gula NM. N-stearoylethanolamine restores pancreas lipid composition in obesity-induced insulin resistant rats. Lipids. 2015; 50(1): 13-21.

13. Svegliati-Baroni G, Candelaresi C, Saccomanno S, Ferretti G, Bachetti T, Marzioni M, De Minicis S, Nobili L, Salzano R, Omenetti A, Pacetti D, Sigmund S, Benedetti A, Casini A. A model of insulin resistance and nonalcoholic steatohepatitis in rats: role of peroxisome proliferator-activated receptor-alpha and n-3 polyunsaturated fatty acid treatment on liver injury. Am J Pathol. 2006; 169(3): 846-860.

14. Onopchenko OV, Kosiakova GV, Meged EF, Klimashevsky VM, Hula NM. The effect of $\mathrm{N}$-stearoylethanolamine on cholesterol content, fatty acid composition and protein carbonylation level in rats with alimentary obesity-induced insulin resistance. Ukr Biochem J. 2014; 86(6): 119-128.

15. Collier GR, Chisholm K, Sykes S, Dryden PA, O'Dea K. More severe impairment of oral than intravenous glucose tolerance in rats after eating a high fat diet. J Nutr. 1985; 115(11): 1471-1476.

16. Epps DE, Natarajan V, Schmid PC, Schmid HO. Accumulation of $\mathrm{N}$-acylethanolamine glycerophospholipids in infarcted myocardium. Biochim Biophys Acta. 1980; 618(3): 420-430. 
17. Rodbell M. Metabolism of isolated fat cells. I. Effects of hormones on glucose metabolism and lipolysis. J Biol Chem. 1964; 239: 375-380.

18. Mueller WM, Gregoire FM, Stanhope KL, Mobbs CV, Mizuno TM, Warden CH, Stern JS, Havel PJ. Evidence that glucose metabolism regulates leptin secretion from cultured rat adipocytes. Endocrinology. 1998; 139(2): 551558.

19. Bligh EG, Dyer WJ. A rapid method of total lipid extraction and purification. Can J Biochem Physiol. 1959; 37(8): 911-917.

20. Vaskovsky VE, Terekhova TA. HPTLC of phospholipid mixtures containing phosphatidylglycerol. $J$ High Resolut Chromatogr Chromatogr Commun. 1979; 2(11): 671-672.

21. Svetashev VI, Vaskovsky VE. A simplified technique for thin-layer microchromatography of lipids. J Chromatogr. 1972; 67(2): 376-378.

22. Vaskovsky VE, Kostetsky EY, Vasendin IM. A universal reagent for phospholipid analysis. J Chromatogr. 1975; 114(1): 129-141.

23. Cerqueira NM, Oliveira EF, Gesto DS, SantosMartins D, Moreira C, Moorthy HN, Ramos MJ, Fernandes PA. Cholesterol Biosynthesis: A Mechanistic Overview. Biochemistry. 2016; 55(39): 5483-5506.

24. Hussain MM, Strickland DK, Bakillah A. The mammalian low-density lipoprotein receptor family. Annu Rev Nutr. 1999; 19: 141-172.

25. Marcuzzi A, Piscianz E, Loganes C, Vecchi Brumatti L, Knowles A, Bilel S, Tommasini A, Bortul R, Zweyer M. Innovative Target Therapies Are Able to Block the Inflammation Associated with Dysfunction of the Cholesterol Biosynthesis Pathway. Int J Mol Sci. 2015; 17(1). pii: E47.

26. Rousset X, Vaisman B, Amar M, Sethi AA, Remaley AT. Lecithin: cholesterol acyltransferase--from biochemistry to role in cardiovascular disease. Curr Opin Endocrinol Diabetes Obes. 2009; 16(2): 163-171.

27. Freeman MW. Managing Your Cholesterol (Harvard Medical School Special Health Reports). Harvard Health Publications, 2015; $50 \mathrm{p}$.

28. Yeagle PL. Cholesterol and the cell membrane. Biochim Biophys Acta. 1985; 822(3-4): 267-287.

29. Fielding CJ, Fielding PE. Membrane cholesterol and the regulation of signal transduction. Biochem Soc Trans. 2004; 32(Pt 1): 65-69.
30. Yeagle PL. Modulation of membrane function by cholesterol. Biochimie. 1991 Oct;73(10):1303-10.

31. van Meer G, Voelker DR, Feigenson GW. Membrane lipids: where they are and how they behave. Nat Rev Mol Cell Biol. 2008; 9(2): 112124.

32. Zeghari N, Younsi M, Meyer L, Donner M, Drouin P, Ziegler O. Adipocyte and erythrocyte plasma membrane phospholipid composition and hyperinsulinemia: a study in nondiabetic and diabetic obese women. Int $J$ Obes Relat Metab Disord. 2000; 24(12): 1600-1607.

33. Gavrilova NJ, Setchenska MS, Markovska TT, Momchilova-Pankova AB, Koumanov KS. Effect of membrane phospholipid composition and fluidity on rat liver plasma membrane tyrosine kinase activity. Int J Biochem. 1993; 25(9): 1309-1312.

34. Makdissy N, Haddad K, Mouawad C, Popa I, Younsi M, Valet P, Brunaud L, Ziegler O, Quilliot D. Regulation of SREBPs by Sphingomyelin in Adipocytes via a Caveolin and Ras-ERK-MAPK-CREB Signaling Pathway. PLoS One. 2015; 10(7): e0133181.

35. Macaulay SL, Larkins RG. Insulin stimulates turnover of phosphatidylcholine in rat adipocytes. Mol Cell Biochem. 1994; 136(1): 23-28.

36. Donchenko V, Zannetti A, Baldini PM. Insulinstimulated hydrolysis of phosphatidylcholine by phospholipase $\mathrm{C}$ and phospholipase $\mathrm{D}$ in cultured rat hepatocytes. Biochim Biophys Acta. 1994; 1222(3): 492-500.

37. Cazzolli R, Huang P, Teng S, Hughes WE. Measuring phospholipase D activity in insulinsecreting pancreatic beta-cells and insulinresponsive muscle cells and adipocytes. Methods Mol Biol. 2009; 462: 241-251.

38. Zolese G, Wozniak M, Mariani P, Saturni L, Bertoli E, Ambrosini A. Different modulation of phospholipase A2 activity by saturated and monounsaturated N-acylethanolamines. J Lipid Res. 2003; 44(4): 742-753.

39. Cornell RB, Taneva SG. Amphipathic helices as mediators of the membrane interaction of amphitropic proteins, and as modulators of bilayer physical properties. Curr Protein Pept Sci. 2006; 7(6): 539-552.

40. Slater SJ, Kelly MB, Taddeo FJ, Ho C, Rubin E, Stubbs CD. The modulation of protein kinase C activity by membrane lipid bilayer structure. J Biol Chem. 1994; 269(7): 4866-4871. 
41. Severson DL, Hurley B. Stimulation of the hormone-sensitive triacylglycerol lipase from adipose tissue by phosphatidylethanolamine. Biochim Biophys Acta. 1985; 845(2): 283-291.

42. Matias I, Gonthier MP, Petrosino S, Docimo L, Capasso R, Hoareau L, Monteleone P, Roche R, Izzo AA, Di Marzo V. Role and regulation of acylethanolamides in energy balance: focus on adipocytes and beta-cells. Br J Pharmacol. 2007; 152(5): 676-690.

43. Lambert DM, Muccioli GG. Endocannabinoids and related $\mathrm{N}$-acylethanolamines in the control of appetite and energy metabolism: emergence of new molecular players. Curr Opin Clin Nutr Metab Care. 2007; 10(6): 735-744.

44. Artmann A, Petersen G, Hellgren LI, Boberg J, Skonberg C, Nellemann C, Hansen SH, Hansen HS. Influence of dietary fatty acids on endocannabinoid and $\mathrm{N}$-acylethanolamine levels in rat brain, liver and small intestine. Biochim Biophys Acta. 2008; 1781(4): 200-212.

45. Mosior M, Newton AC. Mechanism of the apparent cooperativity in the interaction of protein kinase $\mathrm{C}$ with phosphatidylserine. Biochemistry. 1998; 37(49): 17271-17279.
46 Bandyopadhyay G, Sajan MP, Kanoh Y, Standaert ML, Quon MJ, Lea-Currie R, Sen A, Farese RV. PKC-zeta mediates insulin effects on glucose transport in cultured preadipocytederived human adipocytes. J Clin Endocrinol Metab. 2002; 87(2): 716-723.

47. Sweet LJ, Dudley DT, Pessin JE, Spector AA. Phospholipid activation of the insulin receptor kinase: regulation by phosphatidylinositol. FASEB J. 1987; 1(1): 55-59.

48. Onopchenko OV, Kosiakova GV, Goridko TM, Berdyshev AG, Mehed OF, Hula NM. The effect of N-stearoylethanolamine on the activity of antioxidant enzymes, content of lipid peroxidation products and nitric oxide in the blood plasma and liver of rats with induced insulin-resistance. Ukr Biokhim Zhurn. 2013; 85(5): 88-96. (In Ukrainian).

49. Newman JL, Stiers DL, Anderson WH, Schmid HH. Phase behavior of synthetic N-acylethanolamine phospholipids. Chem Phys Lipids. 1986; 42(4): 249-260.

Received 15.03.2018 